\title{
Serving Higher Education's Highest Goals: Assessment of the Academic Library as Place
}

\section{Heather Lea Jackson and Trudi Bellardo Hahn}

\begin{abstract}
An empirical study was conducted using methods borrowed from the psychology of religion (instead of corporate assessment techniques) to assess whether the academic library as place supports students' desire to feel connected to higher education's mission. The findings from an in-person survey of fifty-four students at three universities showed a preference for exterior and interior images of traditional libraries over those classed as modern, and those images evoked feelings of scholarship, engagement, spirituality, and other positive emotions, as well as subjects' desire to use those spaces more than they currently use their existing library.
\end{abstract}

It is not mere courtesy that causes people to become silent in the library, as they do in a church: Libraries are sacred spaces. ${ }^{1}$

In a classic text titled The Sacred and the Profane, Mircea Eliade described how humans experience space, time, nature, and life in religious and nonreligious ways. In regard to space, he contended that all of us, whether religious or not, encounter spaces and places that fill us with a sense of awe, feelings of spirituality, or connectedness to something much larger than ourselves. These spaces are set apart and different from our normal dayto-day spaces - they are "qualitatively different from others." ${ }^{2}$ For people who are religious, these sacred spaces are usually churches (or temples, synagogues, mosques, or shrines). For the nonreligious, entering or being in other spaces (such as a birthplace, the site where you met your first love, or a certain place in the first foreign city you visited in your youth) may invoke powerful feelings.

It was in a seminar on the academic library at the University of Maryland during a classroom discussion about the library as place that a student introduced the idea that an academic library might invoke spiritual feelings in students, or at least make them feel different-more focused on scholarship and more connected to the university's larger mission. The student expressed her concern that, as modern academic libraries change to accommodate the needs and preferences of a new generation of students, they might lose something special in the process. It was difficult for her to express what that special something was, but she said, "Sometimes, when I go into a beautiful traditional library I feel like I'm going into

Heather Lea Jackson is a Consultant for the University of Maryland, e-mail: heatherj@umd.edu; Trudi Bellardo Hahn is Professor of the Practice in the College of Information Studies at the University of Maryland; e-mail: thahn@umd.edu. (C) Heather Lea Jackson and Trudi Bellardo Hahn 
a church. Not because it feels religious, but because I'm filled with a special sense of connectedness to the university's scholarly traditions. The library atmosphere puts me into a totally different frame of mind...I'm ready to read, to think, and to reflect." These observations led to searching of the literature on church ${ }^{3}$ as place and other psychological studies that examine why people react in the ways they do to places they consider "sanctified."

This study was basically about two things: first, whether the look of a traditional library and the objects in it make it special, or "sanctified" for student users and more tied to the university's scholarly mission; and second, whether that specialness is a benefit that can be measured or assessed. On this latter point, we started from the assumption that corporate models of efficacy that focus on the bottom line, customer satisfaction, or activity outputs such as circulation figures or database use statistics are limited in what they can tell us about the library's effectiveness or usefulness and whether it is serving the institution's mission.

Coming back to the original observation, that the feelings of being in a traditional academic library are similar to the spiritual feelings of being in a church, we noted that higher-level religious or spiritual goals are inherently abstract-people go to their houses of worship because they are striving for closeness to God, salvation, and the like. The missions and goals of higher education are similarly abstract. In looking at nearly one hundred mottos and mission statements for colleges and universities, we repeatedly found such abstract concepts as knowledge, truth, light, and wisdom. Most mission statements are variations on this one: "We are dedicated to scholarship, academic achievement, creative accomplishment, cultural enrichment, and social responsibility." Thus the analogy "the academic library is to the university as the church is to God" formed the core of our empirical study.

While we must admit that many, if not most, modern academic libraries fall short of inspiring awe or generating feelings of connectedness to higher scholarly goals, we wanted to explore a method for empirical research on what intuitively seemed to be a yearning among students for such a place on campus.

\section{Assessing Academic Libraries}

The question of how best to measure efficacy of academic libraries has been debated for many years during which most assessment and evaluation studies have focused on modifying corporate or business models. For example, Continuous Quality Improvement, Total Quality Management, Balanced Scorecard, and customer service assessment models are all management and evaluation tools that have had a significant impact on measures of academic library efficacy. ${ }^{4}$ In corporate settings, evaluating performance by establishing these measures of success seems a reasonable approach. Corporations tend to be oriented toward reaching concrete goals (for example, increased worker productivity, profit margin, or sales) that are easily quantified and evaluated for success or failure. While corporate models have beneficial elements that might be applied in library settings, particularly those related to customer service evaluation, they are simply not enough to get the full picture of an academic library's value, and many commentaries on the limitations of such methodologies are in the literature. ${ }^{5}$ These criticisms sensibly question specific trends or the application of such evaluative methods in academic libraries, but rarely are they accompanied by concrete solutions or means for improvement. Generally, authors either champion an alternative corporate model, advocate applying traditional library statistics to a new model of effectiveness, or obliquely draw attention to the neglect of areas critical to library efficacy, but they offer few tangible means of measurement.

Institutions of higher education are typically driven by abstract principles that do not lend themselves to easy numerical examination or even consensus on what 
the product or output should be. ${ }^{6}$ Our survey of college mottoes and mission statements of both public and private institutions of higher education revealed sentiments and goals that are fundamentally abstract or even metaphoric in nature; they do not resemble the quantifiable aims of corporations. Given the intangible nature of a higher education institution's mission, and assuming that its library seeks to support this mission, the usefulness of corporate modeling for comprehensively evaluating the not-forprofit library is questionable.

We do not propose that all existing evaluative measures in academic libraries be abandoned. Instead, given the inherent difficulties in finding corporate models that are relevant to the mission of academic institutions, we put forward a novel approach to evaluating value.

\section{Library as Place}

The concept of library as place has been much en vogue as the field faces a potential crisis related to technological progress and mass digitization. The academic library as a huge structure serving as a repository of a collection of hard-copy knowledge is facing a clear threat to its continued necessity and usefulness in the shape, form, and scale of the past. ${ }^{7}$ In part to fend off claims that the library will soon be irrelevant as collections are digitized and user access is increasingly remote, the idea of library as place having independent merits is garnering support. Many proponents of place focus on changes to draw in students-adding coffee and snack bars, relaxing rules regarding food and drink, installing circular workstations, increasing the number of computers, or scheduling cultural events such as film screenings or musical performances to transform dusty book stacks into fresh, modern, and useful places. Geoffrey Freeman and other writers have emphasized that the library of the future has to accommodate "myriad new information and learning technologies and the ways we access and use them." ${ }^{8}$ Accordingly, library renovations usually result in increased space for group study rooms, instructional facilities, information commons, and wireless access, and other features to support changing learning and teaching modes. ${ }^{9}$

Means for measuring the effectiveness of such changes basically amount to customer satisfaction and preference surveys. However, data from these surveys, even when highly favorable to the changes, ultimately do nothing to stave off claims that the library is simply turning into another student union or computer lab. The data may show that the majority of students are "very happy" with the addition of a library coffee shop or increased numbers of computers and would gladly use them, but they do little to show whether the library itself is effective or useful and do nothing to show how it is supporting the broader mission of the academic institution.

\section{Library as "Sacred Space"}

Several writers have articulated the idea that an academic library is more than just a campus building with collections and services to support study and research. For example, Karen Antell and Debra Engell reported the words of a respondent to an anonymous survey about the special feeling gained from entering the library:

Comfortable chairs and couches, elegantly bound volumes, and encapsulating solitude are a necessary escape.....Nothing can compare to the sensation of walking into a building and being surrounded by the physical sensation of knowledge: seeing books, feeling each page as it turns, smelling the aging paper and ink, and so forth. For me, the physical space of a library creates an environment that has been specifically designed to give a physical and spiritual sensation of knowledge, past experiences, and hope for the future. Electronic resources, no matter how useful, cannot duplicate this experience. ${ }^{10}$ 
In another study, Antell and Engell asserted that the library physical space facilitates a form of concentration in young scholars that is beneficial for progress and academic achievement. Their research highlights the sense of sanctuary in the library and the library as a symbol of academic tradition. ${ }^{11}$

Geoffrey Freeman elaborated on this idea of individuals connecting to the scholarly community and its traditions and ethos just by being in an academic library:

Upon entering the library, the student becomes part of a larger community - a community that endows one with a greater sense of self and higher purpose. Students inform us that they want their library to "feel bigger than they are." They want to be part of the richness of the tradition of scholarship as well as its expectation of the future. They want to experience a sense of inspiration. ${ }^{12}$

Freeman went on to say: "The academic library as place holds a unique position on campus. No other building can so symbolically and physically represent the academic heart of an institution."13

Making a link between libraries and spirituality is not new. Thomas Augst noted that traditional library architecture of the later nineteenth and early twentieth century was redolent of ecclesiastical architecture because libraries had a sacral or spiritual function and were meant as institutions of public culture in the modern age, to invoke religious emotions (he was speaking of public libraries, but his remarks seem attuned to academic libraries as well). ${ }^{14}$ Nancy Maxwell went even further in asserting that librarianship is a "holy" profession; she did not stop at stating that the library is analogous to a church; she claimed that the library is a church, librarians are clergy, and library work is inherently religious. ${ }^{15}$ She supported her thesis primarily with historical review and anecdotal evidence. For purposes of assessment, however, an analogous relationship is more useful and needs no claims of actual religious value of libraries. There is no need to confuse this approach to the library as place with assertions that the academic library has religious significance or is churchlike in any sense other than the notion that people may indeed view it as a tangible representation of the institution's abstract mission.

\section{Context and Methodology Context}

Because of the limitations in extant corporate models of assessment, and because we believe the examination of library as place can be extended if it is contextualized by the work of researchers in the field of psychology of religion, we looked to the latter area for a fresh approach. Psychologists studying religion have conducted extensive research in the area of sanctification and sanctified spaces, which we have applied to assessing the library as place. Kenneth Pargament offered a definition of the sacred that encompasses "concepts of God, the divine, and the transcendent, but it is not limited to notions of higher powers. It also includes objects, attributes, or qualities that become sanctified by virtue of their association with or representation of the holy." 16 He argued that humans have the ability to sanctify secular objects, space and time, events and transitions, cultural products, people, psychological attributes, social attributes and roles. ${ }^{17} \mathrm{He}$ further asserted that:

There may be important consequences of the sanctification process. A job is likely to be approached differently when it becomes a vocation. A marriage likely takes on special power when it receives divine sanction. The search for meaning, community, self, or a better world are likely to be transformed when they are invested with sacred character. ${ }^{18}$

Within that context, the library may be sanctified and given special status 
in the user's mind. Indeed, Pargament claimed that:

...perceptions of divine-like qualities in objects are not necessarily rooted in beliefs in God. Conceivably, an atheist could imbue objects in his or her life with divine-like attributes. Indeed, I suspect that a large proportion of those who disavow beliefs in God hold many aspects of their lives to be sacred. ${ }^{19}$

A researcher on church as place, Lily Kong, noted in her exploration of temporary churches relocated in such places as a modern auditorium, "The structure and architecture of religious buildings influence the ambience of the setting and can play a large role in contributing to or detracting from the divine experience." ${ }^{20}$ Psychology of religion studies have not only reported affective benefit toward reaching spiritual goals simply due to being in a sanctified space; they also have demonstrated increased emotional, financial, and time investment in such places. ${ }^{21}$

From an extensive body of research focused on personal strivings and the usefulness of tangible representations of abstract goals in achievement, the psychology of religion offers rigorously developed measures for looking at abstract concepts. ${ }^{22}$ With modifications that make these measures relevant and specific to the academic setting, these research methods not only offer a means to look at how the library serves the university but also provide a direct means for showing its usefulness to the individuals in the university community.

The role of the library as a support for the members of an academic community is also worth examining from the angle of sanctification. Peter Hill and Kenneth Pargament ${ }^{23}$ and Robert Kahn and Toni Antonucci ${ }^{24}$ depict the church as a "support convoy." Psychological measures have demonstrated that the social and religious support of a church "can be a valuable source of self-esteem, informa- tion, companionship, and instrumental aid that buffers the effects of life stressors or exerts its own main effects." ${ }^{25}$ While the congregation and clergy of a church might change, just as the staff of a given academic library do, the institution itself stands as a support system where the individual feels able to seek and find direction and support at any time. In this context, the academic library may also be seen as an unchanging conduit to the university's abstract goals. This concept of library as place is analogous to studies showing the importance of church as place in terms of focusing the benefit to congregants while in the physical structure. ${ }^{26}$

Modification of questions in measures of strivings and sanctification can be applied to library evaluation, following the natural trajectory of Antell and Engel's findings that suggested that students do value the physical library's conduciveness to scholarship. ${ }^{27}$ Given Antell and Engel's questions as to whether physical materials matter to the concepts of library as space, it is imperative to focus on these physical materials in any questionnaire addressing the sanctification of the library, as it is possible that there is an iconography of library concurrently at play. Perhaps removing stacks and physical materials would be detrimental to the positive impact of the library as space, much as removing all the crosses from a Christian church might make the church feel less sacred. Up until now we have not had a clear means for examining the role of physical materials other than simple utility. However, in some facilities, librarians have fought to keep the card catalog in the library, despite its being redundant in combination with the computerized catalog system. The idea of keeping an object that is inextricably tied to libraries, but is functionally obsolete and useless, may be intuitively accounting for an iconographic factor that we have not as of yet been able to demonstrate. A possible argument against this type of measure might assert that only generations brought up in the "old" library 
would embrace the traditional elements of the library. Nevertheless, Antell and Engel's work demonstrated that younger users were the most likely to draw a clear connection between library as place and increased aptitude for scholarly pursuits.

\section{Design and Methodology}

The 54 subjects were currently enrolled students at the University of Arizona, University of Illinois at Urbana-Champaign, or University of Maryland. They were a mix of males and females, undergraduates and graduate students, and represented a wide range of ages and a mix of 30 different majors. Subjects were presented in person with a paper survey (see appendix for a version of the survey) and a flipbook of images to examine while they answered the questions.

Each survey incorporated twelve questions to assess demographics, current library and electronic resource usage, and self-identification with attributes (technological proficiency, scholarship, sociability, and spirituality). Respondents were then asked questions related to a series of images of academic libraries and items that may be found in libraries, reproduced in high resolution color in the flipbook. Architectural styles and items were categorized as either "modern" or "traditional" based on results of an image-norming study. ${ }^{28}$ The images presented to any given subject included a mix of "modern" and "traditional" style library exteriors, interiors, or items.

A text vignette or brief description (see survey form in the appendix) accompanied each image. Adding a vignette limited the subjects to responding to the actual building itself. Without a vignette, a subject may view a picture with a preexisting set of assumptions or expectations regarding collection size, hours of operation, technological sophistication, or staffing levels. This could easily bias responses, so the vignettes read exactly the same for the modern and traditional image for each matched pair, thus creating a control so that the only thing respondents were making judgments about was the building itself. The vignette style is common in psychology and public opinion studies. ${ }^{29}$ The combination of images and vignettes is actually preferable to using a real building, as the latter is likely to carry "baggage" that will have an unknown influence on subjects' responses.

The design also used one image of each type to correlate with the vignettes primarily for statistical simplicity-it reduced the independent variables and allowed for split-ballot randomization. This then allowed for more conservative analysis (by t-test and ANOVA) of dependent variables in the subexperiments. Everyone viewed exterior and interior shots of traditional and modern buildings, interiors, and items, but no one saw both sets of any pair (the two images corresponding to a given vignette).

For the exterior images, subjects were asked questions to assess their affective response to the image, predicted use of materials in that library, and predicted use of that library space. For the first interior image, subjects were presented with the same questions to assess their affective response. For the second interior image, subjects were asked to imagine being inside the pictured library and to pick from a series of six adjectives to best describe their feelings while using the library. The second question asked subjects to circle a phrase best describing the purpose for which they would most likely use the pictured library. Subjects were then presented with two questions asking them to assess how well the pictured library supports a motto and mission statement of the institution. ${ }^{30}$

Affective response to each image was elicited by a set of subexperiments, one being designed with Likert scale responses, another being a set of "feeling" pairs (see the sample survey in the Appendix). With the matched pairs on the feeling items, it was easier to present the respondent with a forced-choice scenario, as this counteracted the phenomenon that people generally skew to the most neutral option on surveys. ${ }^{31}$ By our not offering 
a neutral, subjects did not have that option. Also, presenting a number of pairs focusing on other feeling groups masked the spiritual/secular pairs. This controlled against subjects attempting to please the interviewer by providing the answer they believe the interviewer wanted.

For the first image of an item, subjects were asked about the item's perceived usefulness and predicted likelihood of using it. For the second item image, subjects were asked about their initial affective response to the item and their predicted use of it. For all the images, subjects were presented with a series of 14 binary pairs of adjectival antonyms (feeling pairs) and asked to choose the adjective in each pair that best described their emotional response to the image. All these questions provided a data set of 84 items per subject.

\section{Study Findings and Conclusions}

The data analysis revealed that the subjects expressed an overall preference for those images classed broadly across all areas (exterior, interior, items) as traditional versus those classed as modern. On all items assessing affective response to the images, the traditional images were given a coded mean score of 3.7 on a scale of 1 to 4 with 4 representing the most positive affective response, whereas modern images were given a coded mean score of 2.5 across all subjects (see figure 1). This difference was highly significant with $p<.0001$ both in a one-way analysis of variance (ANOVA) and in a t-test.

Style of architecture also was significant when analyzed as a predictor for increased or decreased hypothetical use of the pictured libraries' materials from the actual reported use of the subjects' current library. Responses to questions regarding actual use of each subject's current library were coded so that responding "daily" was scored as a 4 ranging down to a score of 1 for "less than once a month." The correlate questions regarding use of the hypothetical library were coded so that "frequently" was scored as a 4 ranging down to a score of 1 for "never." This coding was done conservatively (with "frequently" equating with "daily" actual reported use) so as to minimize effects of overreporting hypothetical use. Mean coded score for frequency of use for traditional images was 3.46 versus 3.15 for modern. Analysis of variance using all subjects' reported

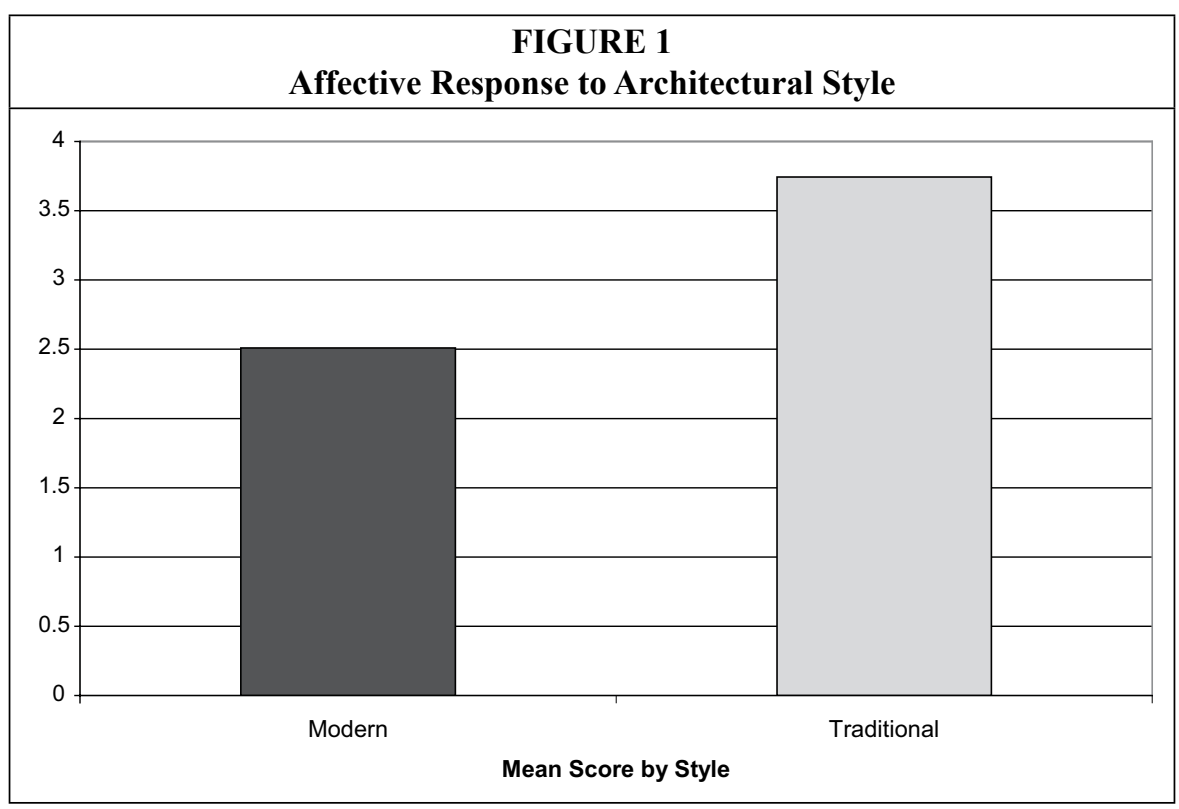


current use and style of library as a factor for likelihood of use revealed a $\mathrm{p}$ value of $<.016$, which is statistically significant. Subjects were likely to predict that they would use the pictured modern libraries slightly less than they currently use their existing library. Conversely, they were likely to predict that they would use the pictured traditional libraries (exterior and interior non-item-level images) much more than they currently use their library with an increase of an entire point in the scale by mean. A strong effect on hypothetical visits to the libraries based on modern or traditional designation was also observed in a t-test with a $\mathrm{p}<.0001$. Subjects were more likely to express frequent visits to the buildings categorized as traditional architecture by over half a point difference in mean score (3.54 for traditional versus 3.0 for modern). Additionally, the subjects classified the traditional library exteriors and interiors as spiritual rather than secular. They reported a more positive affective response to those spaces categorized as spiritual and traditional (3.64 affective mean score for spiritual versus 2.44 for secular; 3.7 mean for traditional versus 2.5 for modern), as well as increased desire to use the materials in the traditional library and the library space itself. The spiritual designation of the pictured library showed a significant effect on predicted use over the secular library (mean score 3.54 for spiritual versus 3.15 for secular), with a $\mathrm{p}<.026$ (see figure 2).

The spiritual designation was also a strong predictor of whether subjects believed the library was supporting the university's goals (motto and mission). Examination of the correlation by t-test between spiritual designation and view of effective support of the motto showed a $p$ value of $<.00022$, with means of 3.41 for spiritual versus 2.58 for secular. Spiritual designation and prediction of mission effectiveness was also highly significant with $\mathrm{p}<.0001$, with means of 3.71 for spiritual versus 2.68 for secular. Figure 3 shows the strong difference in means of reported support of the university's motto and mission statement.

However, the spiritual designation did not have an effect on subjects' responses to questions at the item level (such as a card catalog). Interestingly, the positive nature of the "spiritual" designation at the item level did not seem to outweigh the

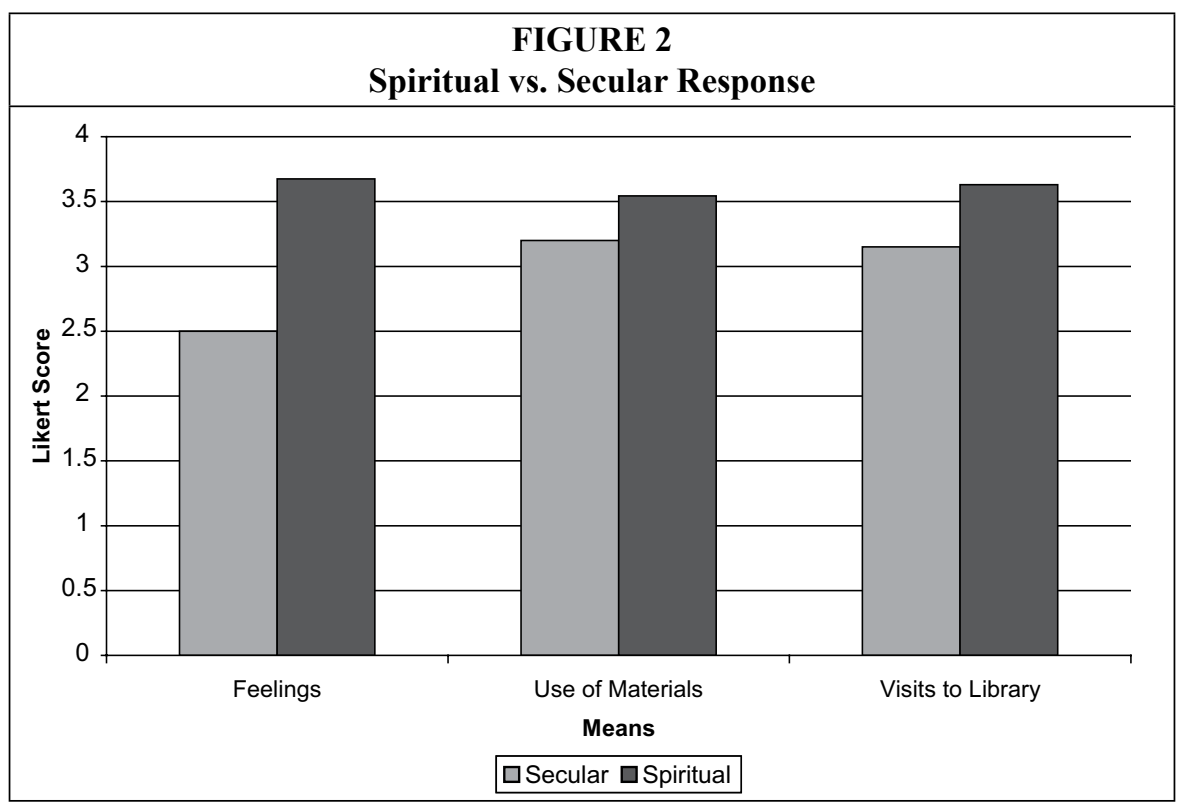




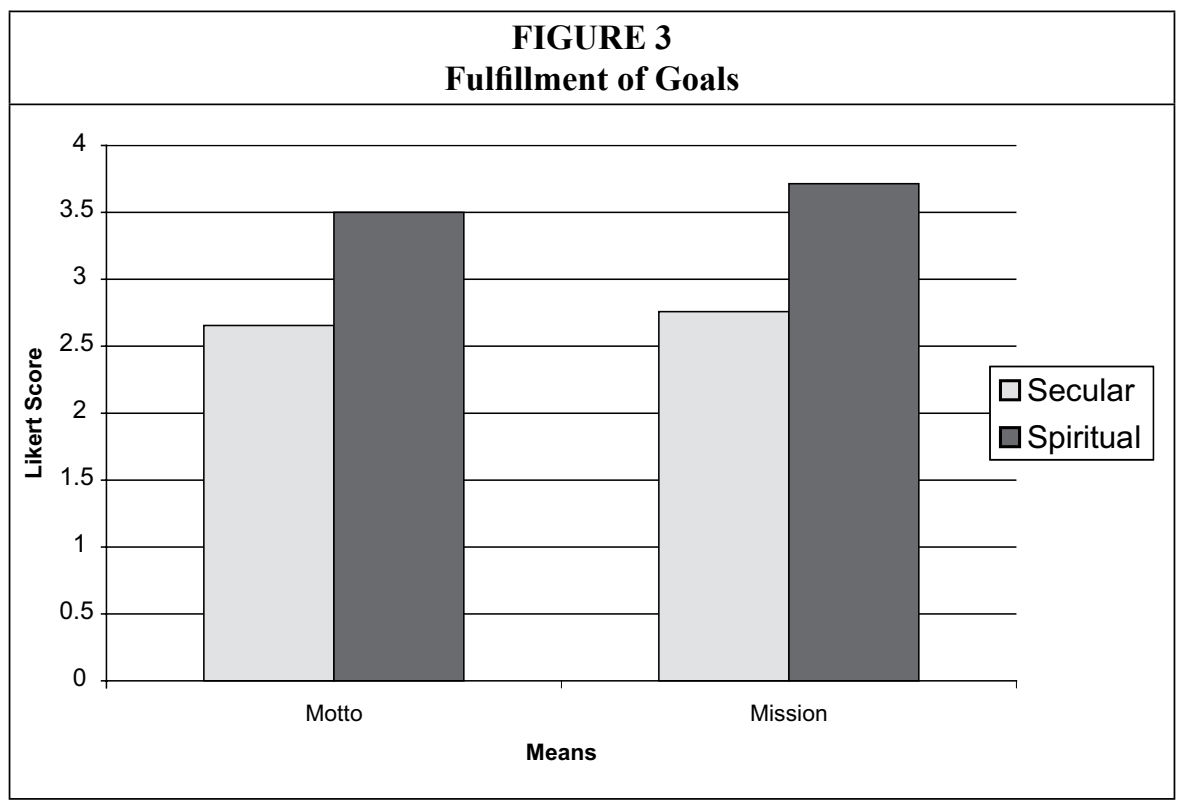

impact of the item's perceived usefulness. While no significant effect of the spiritual/ secular designation was seen on subject responses at the item levels beyond the affective response, subjects' perceptions of usefulness had a significant effect on the other responses to item questions. Mean scores indicated a more positive affective response to the "spiritual" items, but this designation did nothing to predict likelihood of use or view of usefulness. A positive score for item usefulness with $\mathrm{p}<.02$ significantly predicted use likelihood and frequency of use. This indicates a much more utilitarian decision-making process about use of individual items. This stands in sharp contrast to the apparently feeling-based decision-making process about use of the library building or use of the interior space.

As Antell and Engel's study on the library as place demonstrated, there is clearly an affective benefit of the physical space that up until now has not been fully explored beyond remarking that it is surprising. ${ }^{32}$ This empirical study affirmed our hypothesis that spaces deemed as "sacred" or "sanctified" produce affective benefits for people that extend beyond attitudes and into the realm of behav- ior (projected library use). Circulation statistics do not measure these benefits; students may not actually use the books on the shelves, but they "sanctify" the books-being around the books makes them feel more scholarly and connected to the institution's educational mission. This type of response is borne out in the literature examining the affective responses to sacred spaces. Being in the presence of sanctified objects increases the worshipper's spiritual experience even if the worshipper does not technically "use" the objects. Within this context, the overall contribution of "spiritual" library items to the greater sacred ambience should not be taken lightly. While students clearly value computers in libraries, paradoxically they do not like tech-heavy-looking spaces; students want new technologies presented in traditional academic surroundings. These findings have implications for new construction and remodels.

\section{Interpretations and \\ Recommendations}

Our study demonstrates that borrowing evaluation methodologies from the field of psychology of religion or the architecture of sacred spaces may offer 
the campus library a viable alternative to assessing its usefulness as place, in terms of abstract academic goals necessitating the physical library in its traditional form.

If asked, students may not state that they want visible stacks in the library; in fact, if asked whether they intend to use the books on the shelves, they may say they have no intention of using them. However, if the stacks are taken completely away, they may feel a keen detrimental effect. Therefore, it is important to examine the academic library from this affective perspective prior to planning new construction or making any drastic changes in the design and model of the traditional library, rather than relying on student input in the simplistic form of "Please let us know what you'd like to see in the new library." While students may request a coffee shop, computer stations, and the latest technology, this cannot reflexively be considered to be a wish for those things to the exclusion of more traditional design and items. Traditional and modern elements can happily coexist, but careful planning and sensitivity to these subtle, but significant, desires are required.

In reporting our preliminary findings in August 2008 at an international conference, we received strong affirmation from the audience about these conclusions. ${ }^{33}$ Nevertheless, this study could be expanded with larger numbers of students, and perhaps also faculty, and involve a greater variety of institutions of higher education, to verify the reliability of the method and probe the validity of the findings more deeply. For example, it would be interesting to know how academic library patrons view the library in general. Does it help them to feel connected to the university's mission? Or do they even care about the university's mission? Another point to explore would be how often the respondents used the library (that is, entered the building rather than accessed the collection remotely) and their perceptions of that experience.
Finally, we believe that this methodology could be adapted and applied to other areas. In the area of online resource use and user interface design, if one were designing a new library Web site, potential users could be presented with a static image of the page and then asked questions about it. Even better, the virtual space could be imagined in the same way as we have conceptualized the physical space, and affective responses could be elicited as well as use predictors from users. A vignette could be offered that prompts a user to do something complex with the interface, to elicit intuitions about where someone would start-for example, the user sees a dummy page and a vignette requests a search for an article about $X$. What would be the user's first step? The user could then be asked for feelings about the task and the interface, as library anxiety can extend to the virtual library as well.

Another application of this methodology could be to the study of public library as place-there may not be sanctification in a religious sense occurring in the public library, but a similar experimental design could be used to examine what, if anything, was being valued in a similar way (perhaps community, safety, or knowledge, as these feelings and goals have been identified as vital to successful religious architecture). The public library has different goals from academic libraries, but there is no reason that a similar methodology would not elicit useful data about what people expect/ want/need when they think of public library spaces. Samuel Demas and Jeffrey Scherer ${ }^{34}$ have described public libraries as "transcendent spaces" and Marylaine Block $^{35}$ described the public library as the "heart of the community," but this methodology would offer researchers a more sophisticated way to conduct an empirical study to measure exactly how a community responds to specific elements of library as place. 


\section{APPENDIX \\ Survey of Attitudes toward Academic Libraries}

Please circle only one response for each of Questions 1-4 and 6-12.

1. Gender: $\square$ Male $\square$ Female

2. Age: $\square$ 15-19 $\square$ 20-24 $\square$ 25-29 $\square$ 30-39 $\square$ 40-49 $\square$ 50+

3. Student status:

Undergraduate: $\square$ Freshman $\square$ Sophomore $\square$ Junior $\square$ Senior Graduate: $\square$ Master's student $\square$ Doctoral student

Other:

4. Enrollment status: $\square$ Part-time $\square$ Full-time

5. Major field of study: (fill in the blank)

6. How frequently do you use your campus library?
$\square$ Daily
Weekly
Monthly
Less than once a month

7. How frequently do you use the electronic resources provided by your campus library?
Daily
$\square$ Weekly
Monthly
$\square$ Less than once a month

8. How frequently do you use Google Scholar?

$\square$ Daily $\square$ Weekly $\square$ Monthly $\square$ Less than once a month

9. Do you consider yourself a technologically savvy person?

$\square$ Very much $\square$ Somewhat $\square$ Not at all

10. Do you consider yourself a scholarly person?

$\square$ Very much $\square$ Somewhat $\square$ Not at all

11. Do you consider yourself a "people person"?

$\square$ Very much $\square$ Somewhat $\square$ Not at all

12. Do you consider yourself a spiritual or religious person?

$\square$ Very much $\square$ Somewhat $\square$ Not at all

\section{Please examine the image marked "A" in the booklet.}

This is a picture of the exterior of the main library on the campus of a large American research university. This library is the primary building housing the general collection and serves undergraduate and graduate students, university faculty, and staff. The library system contains over 6 million volumes. The library is open 7 days a week. The library offers reference services, special collections, study areas, and access to computers, copiers, and printers.

\section{Please answer the following questions regarding this library}

1. My initial feelings about this library are

$\square$ Very positive $\square$ Somewhat positive $\square$ Somewhat negative $\square$ Very negative 
2. As a member of this campus community, Iwould use the materials in this library

$\square$ Frequently $\square$ Sometimes $\square$ Infrequently $\square$ Never

3. As a member of this campus community, I would visit the main library building

$\square$ Frequently $\square$ Sometimes $\square$ Infrequently $\square$ Never

Please reexamine the image. For each of the following pairs, please circle the word that best describes your immediate emotional response to the image.

$\begin{array}{llll}\begin{array}{l}\text { Overwhelmed } \\ \text { Comfortable }\end{array} & \begin{array}{l}\text { Bored } \\ \text { Engaged }\end{array} & \begin{array}{l}\text { Happy } \\ \text { Sad }\end{array} & \begin{array}{l}\text { Connected } \\ \text { Detached }\end{array} \\ \begin{array}{l}\text { Focused } \\ \text { Distracted }\end{array} & \begin{array}{l}\text { Self-sufficient } \\ \text { Dependent }\end{array} & \begin{array}{l}\text { Chaotic } \\ \text { Systematic }\end{array} & \begin{array}{l}\text { Isolated } \\ \text { Accompanied }\end{array} \\ \begin{array}{l}\text { Scholarly } \\ \text { Ignorant }\end{array} & \begin{array}{l}\text { Energized } \\ \text { Lethargic }\end{array} & \begin{array}{l}\text { Directed } \\ \text { Aimless }\end{array} & \\ \text { Studious } & \text { Disorganized } & \text { Spiritual } & \\ \text { Leisurely } & \text { Organized } & \text { Secular } & \end{array}$

\section{Please examine the image marked " $B$ " in the booklet}

This is a picture of the interior of the main library on the campus of a large American research university. This library is the primary building housing the general collection and serves undergraduate and graduate students, university faculty, and staff. The library system contains over 6 million volumes. The bulk of the collection is housed in this building and is accessible in the stacks when the library is open. The library is open 7 days a week. The library offers reference services, special collections, study areas, and access to computers, copiers, and printers.

\section{Please imagine yourself inside the library pictured}

1. My initial feelings about this library are

$\square$ Very positive $\square$ Somewhat positive $\bar{\square}$ Somewhat negative $\square$ Very negative

2. As a member of this campus community, Iwould use the materials in this library

$\square$ Frequently $\square$ Sometimes $\square$ Infrequently $\square$ Never

3. As a member of this campus community, I would visit the main library building

$\square$ Frequently $\square$ Sometimes $\square$ Infrequently $\square$ Never

Please reexamine the image. For each of the following pairs, please circle the word that best describes your immediate emotional response to the image.

[Insert list of pairs that describe immediate emotional response to the image]

\section{Please examine the image marked " $C$ " in the booklet.}

This is a picture of the interior of the main library on the campus of a large American research university. This library is the primary building housing the general collection and serves undergraduate and graduate students, university faculty, and staff. The library system contains over 6 million volumes. The bulk of the collection is housed in a remote location and can be accessed by request. The library is open 7 days a week. 
The library offers reference services, special collections, study areas, and access to computers, copiers, and printers.

\section{Please imagine yourself inside the library pictured:}

Circle the word that best describes your feelings as you are using this library.

Overwhelmed Focused Distracted Scholarly Bored Energized

1. Circle the phrase that best described the purpose for which you would be most likely to use this library:

Independent study

Group study

Using hard-copy materials (books, journals, microfiche, special collections)

Using electronic library resources (online articles, journals, books, images)

Using general electronic resources (Web pages, online articles, blogs)

Using equipment and technology provided by the library (computers, copiers)

2. The motto of the university that this library is part of is "knowledge and truth." How well do you feel this library supports these values?
$\square$ Strongly
$\square$ Somewhat
$\square$ Minimally
Not at all

3. The mission statement of the university is: "We are dedicated to scholarship, academic achievement, creative accomplishment, cultural enrichment, and social responsibility." How well do you feel this library supports this mission?
$\square$ Strongly
$\square$ Somewhat
Minimally
Not at all

Please reexamine image "C." For each of the following pairs, please circle the word that best describes your immediate emotional response to the image.

[Insert list of pairs that describe immediate emotional response to the image]

\section{Please examine the image marked " $D$ " in the booklet.}

This is a picture of an item or items in the main library of a large American research university.

1. Please indicate your agreement with the statement: the item pictured is useful. $\square$ Strongly agree $\square$ Agree somewhat $\square$ Disagree somewhat $\square$ Strongly disagree

2. How likely are you to use the pictured item?

$\square$ Extremely likely $\square$ Somewhat likely $\square$ Unlikely $\square$ Will definitely not use

Please reexamine the image. For each of the following pairs, please circle the word that best describes your immediate emotional response to the image.

[Insert list of pairs that describe immediate emotional response to the image]

\section{Please examine the image marked " $E$ " in the booklet.}

This is a picture of an item or items in the main library of a large American research university. 
1. My initial feelings about this item are

$\square$ Very positive $\square$ Somewhat positive $\square$ Somewhat negative $\square$ Very negative

2. I would use this item

$\square$ Frequently $\square$ Sometimes $\square$ Infrequently $\square$ Never

\section{Please reexamine image "E." For each of the following pairs, please circle the word that best describes your immediate emotional response to the image.}

[Insert list of pairs that describe immediate emotional response to the image]

\section{Notes}

1. Thomas H. Benton, "A Laboratory of Collaborative Learning," Chronicle of Higher Education 55, no. 43 (2009): A33.

2. Mircea Eliade, The Sacred and the Profane; the Nature of Religion, trans. Willard R. Trask (New York: Harper \& Row, 1957), 20.

3. In this study, the term "church" refers to any religious structure such as a temple, synagogue, mosque, or shrine.

4. John Budd, The Changing Academic Library: Operations, Culture, Environments (Chicago: Association of College and Research Libraries, a division of the American Library Association, 2005); Robert E. Dugan and Peter Hernon, "Outcomes Assessment: Not Synonymous with Inputs and Outputs," Journal of Academic Librarianship 28, no. 6 (2002) 376-80; Sarah M. Pritchard, "Library Benchmarking: Old Wine in New Bottles?" Journal of Academic Librarianship 21, no. 6 (1995) 491-95; Sharon A. Weiner, "Library Quality and Impact: Is There a Relationship between New Measures and Traditional Measures?" Journal of Academic Librarianship 31, no. 5 (2005) 432-37.

5. For example, Dugan and Hernon, "Outcomes Assessment"; Pritchard, "Library Benchmarking."

6. Stephen E. Atkins, The Academic Library in the American University (Chicago: American Library Association, 2003).

7. Scott Carlson, "The Deserted Library," Chronicle of Higher Education 48, no. 12 (2001) A35; Scott Carlson, "Library Renovation Leads to Soul Searching at Cal Poly," Chronicle of Higher Education 53, no. 2 (2006) 63.

8. Geoffrey T. Freeman, "The Library as Place: Changes in Learning Patterns, Collections, Technology, and Use," in Library as Place: Rethinking Roles, Rethinking Space (Washington, D.C.: Council on Library and Information Resources, 2005), 1-9.

9. Harold B. Shill and Shawn Tonner, "Does the Building Still Matter? Usage Patterns in New, Expanded, and Renovated Libraries, 1995-2002," College and Research Libraries 65, no. 2 (2004) 123-50.

10. Karen Antell and Debra Engel, "Stimulating Space, Serendipitous Space: Library as Place in the Life of the Scholar," in The Library as Place: History, Community, and Culture, eds. John E. Buschman and Gloria J. Leckie (Westport, Conn.: Libraries Unlimited, 2007), 163-176.

11. _ "Conduciveness to Scholarship: The Essence of the Academic Library as Place," College and Research Libraries 67, no. 6 (2006) 536-60.

12. Freeman, "The Library as Place," 6.

13. Ibid., 9.

14. Thomas Augst, "Faith in Reading: Public Libraries, Liberalism, and the Civil Religion," in Institutions of Reading: the Social Life of Libraries in the United States, eds. Thomas August and Kenneth Carpenter (Amherst: University of Massachusetts Press, 2007) 148-83.

15. Nancy Kalikow Maxwell, Sacred Stacks: The Higher Purpose of Libraries and Librarianship (Chicago: American Library Association, 2006).

16. Kenneth I. Pargament, "The Psychology of Religion and Spirituality? Yes and No," International Journal for the Psychology of Religion 9, no. 1 (1999), 3-16.

17. Nichole A. Murray-Swank, Kenneth I. Pargament, and Annette Mahoney, "At the Crossroads of Sexuality and Spirituality: The Sanctification of Sex by College Students," International Journal for the Psychology of Religion 15, no. 3 (2005) 199-219.

18. Pargament, "The Psychology of Religion and Spirituality? Yes and No."

19. Kenneth I. Pargament, "The Psychology of Religion and Spirituality? Response to StifossHanssen, Emmons, and Crumpler," International Journal for the Psychology of Religion 9, no. 1 (1999), 
$35-43$.

20. Lily Kong, "The Sacred and the Secular: Exploring Contemporary Meanings and Values for Religious Buildings in Singapore," Southeast Asian Journal of Social Science 20, no. 1 (1992) 18-42.

21. Kenneth I. Pargament, "Of Means and Ends: Religion and the Search for Significance," International Journal for the Psychology of Religion 2, no. 4 (1992) 201-29.

22. Examples include Will Slater, Todd W. Hall, and Keith J. Edwards, "Measuring Religion and Spirituality: Where Are We and Where Are We Going?" Journal of Psychology and Theology 29, no. 1 (2001) 4-21 ; Steven P. Laird et al., "Measuring Private Prayer: Development, Validation, and Clinical Application of the Multidimensional Prayer Inventory," International Journal for the Psychology of Religion 14, no. 4 (2004) 251-72; Jonathan Fox and Shmuel Sandler, "Quantifying Religion: Toward Building More Effective Ways of Measuring Religious Influence on State-Level Behavior," Journal of Church and State 45, no. 3 (2003) 559-88; Nalini Tarakeshwar, Kenneth I. Pargament, and Annette Mahoney, "Measures of Hindu Pathways: Development and Preliminary Evidence of Reliability and Validity," Cultural Diversity and Ethnic Minority Psychology 9, no. 4 (2003) 316-32.

23. Peter C. Hill and Kenneth I. Pargament, "Advances in the Conceptualization and Measurement of Religion and Spirituality: Implications for Physical and Mental Health Research," American Psychologist 58, no. 1 (2003) 64-74.

24. Robert L. Kahn and Toni C. Antonucci, "Convoys over the Life Course: Attachment, Roles, and Social Support," in Life Span Development and Behavior, ed. P.B. Baltes and O.G. Brim (New York: Academic Press, 1980), 253-86.

25. Hill and Pargament, "Advances in the Conceptualization and Measurement of Religion and Spirituality," 69.

26. Kong, "The Sacred and the Secular."

27. Antell and Engel, "Conduciveness to Scholarship"; Robert A. Emmons, "Personal Strivings: An Approach to Personality and Subjective Well-Being," Journal of Personality and Social Psychology 51 (1986) 1058-1068.

28. Rather than rely solely on our own subjective opinions about which images were representative of "traditional" or "modern" library exteriors and interiors, we followed the guidelines of the American Psychological Association, The Standards for Education and Psychological Testing, and devised a norming study by asking a group of colleagues to evaluate several images on a spectrum from traditional to modern using a Likert scale.

29. For example, Jeffrey H. Greenhaus and Gary N. Powell, "When Work and Family Collide: Deciding between Competing Role Demands," Organizational Behavior and Human Decision Processes 90, no. 2 (2003) 291-303; Arthur Van Soest et al., "Validating the Use of Vignettes for Subjective Threshold Scales: Iza Discussion Paper No. 2860," in Center Discussion Paper Series No. 2007-43; RAND Working Paper No. WR-501 (Bonn, Germany: Institute for the Study of Labor (IZA), 2007), available online at http://ssrn.com/abstract=995403 [accessed 21 March 2008].

30. The university motto used was "knowledge and truth" and the mission statement was "We are dedicated to scholarship, academic achievement, creative accomplishment, cultural enrichment, and social responsibility."

31. Jean M. Converse and Stanley Presser, Survey Questions: Handcrafting the Standardized Questionnaire, Quantitative Applications in the Social Sciences Series (Thousand Oaks, Calif.: Sage Publications, 1986).

32. Antell and Engel, "Conduciveness to Scholarship."

33. Trudi Bellardo Hahn and Heather Jackson, "Library as Sacred Space: Applying the Psychology of Religion to the Academic Library as Sanctified Space and Implications for Measurement and Evaluation," in 74th IFLA General Conference and Council (Quebec, Canada: 2008).

34. Samuel G. Demas and Jeffrey A. Scherer, "Esprit de Place: Maintaining and Designing Library Buildings to Provide Transcendent Spaces," American Libraries 33, no. 4 (2002).

35. Marylaine Block, The Thriving Library; Successful Strategies for Challenging Times (Medford, N.J.: Information Today, Inc., 2007). 